\title{
Bank credit in uncertain times: Islamic vs. conventional banks
}

\author{
Mehmet Huseyin Bilgin \\ Faculty of Political Science, Istanbul Medeniyet University, Istanbul, Turkey \\ E-mail: bilginmh@gmail.com \\ Gamze Ozturk Danisman \\ Faculty of Management, Kadir Has University, Istanbul, Turkey \\ E-mail: gamze.danisman@khas.edu.tr

\section{Ender Demir} \\ Faculty of Tourism, Istanbul Medeniyet University, Istanbul, Turkey \\ E-mail: ender.demir@medeniyet.edu.tr \\ Amine Tarazi \\ Université de Limoges, LAPE, 5 rue Félix Eboué, 87031 Limoges Cedex, France. \\ \& Institut Universitaire de France (IUF), 1 rue Descartes, 75231 Paris Cedex 05, France \\ E-mail: amine.tarazi@unilim.fr
}

\begin{abstract}
This paper explores whether the impact of economic uncertainty on credit growth differs for Islamic vs. conventional banks. Using a sample of 416 banks (58 Islamic and 358 conventional) in 12 countries, the findings indicate that an increase in economic uncertainty significantly decreases the credit growth of conventional banks but does not have any significant impact on Islamic banks' credit growth. Our results are robust to alternative specifications and addressing endogeneity concerns using GMM estimators. We further observe that our findings are stronger for the following countries: (1) countries with explicit deposit insurance protection system for Islamic banks, (2) lower foreign dominance, and (3) countries with a higher share of deposits and assets in Islamic banks.
\end{abstract}

Keywords: Economic Uncertainty, Credit, Islamic Banks, Conventional Banks JEL Classification: E50, G21, D81, C23 


\section{Introduction}

Comparison of Islamic and conventional banks with regards to profitability, lending behavior, risk-taking, deposit growth, and stock market returns has received a rising attention especially with the increasing share of Islamic banking in the financial system and their resistance to the global crisis (Khediri et al. 2015). Some studies have documented that their resilience during the global crisis is due to regulations being guided by Shariah principles in which the interest receipt or payments is prohibited and risk-sharing is encouraged between creditors and borrowers (Hasan and Dridi, 2011, Beck et al., 2013). A strand of this literature focuses on whether Islamic banks (IBs) and conventional banks (CBs) are differently affected by economic downturns. Hasan and Dridi (2011) show that IBs' credit growth is higher than that of CBs during the 2007-2009 period and that credit growth of IBs is less affected by the crisis. This draws attention to the importance of the role played by IBs for economic and financial stability. In a comprehensive study including 510 banks (88 Islamic banks) over the 1995-2009 period, Beck et al. (2013) find that Islamic Banks are able to keep a higher loandeposit ratio compared to conventional banks during domestic crisis periods. Consequently, the lending behavior of Islamic banks is likely to be less affected than that of conventional banks during economic downturns. Ibrahim (2016) show that conventional banks tend to be pro-cyclical implying that a decline in GDP growth leads to a decrease in loan growth in Malaysia. On the contrary, the lending behavior of Islamic banks is not influenced by business cycles and can thus be considered as counter-cyclical. This finding supports the view that Islamic banks could play a stabilizing role for the economy. By using data of 25 Islamic banks and 114 conventional banks from 10 dual-banking countries, Ibrahim and Rizvi (2018) show that there is no significant difference in the lending growth of Islamic and conventional banks during normal periods. However, such behavior differs during crisis periods implying that the lending growth of conventional banks decreases during the crisis period while Islamic banks are immune to the crisis.

This paper builds upon this literature by considering the effect of economic uncertainty (EU) developed by Ahir et al. (2018) as a determinant of the lending behaviors of Islamic and conventional banks. Following the spirit of Baker et al. (2016) who propose a measure of Economic Policy Uncertainty (EPU), Ahir et al. (2018) introduce the World Uncertainty Index (WUI) by counting the frequencies of the word "uncertainty" (and its variants) in the Economist Intelligence Unit (EIU) country reports. While previous studies use crisis periods to examine and compare their effect on IBs and CBs, our aim is to investigate, in a broader framework, how such differences can be driven more generally by the degree of uncertainty, 
which is present in both normal times and times of crisis. We hence consider an indicator which can track the economic uncertainty on a continuous basis.

Some papers have investigated the influence of EPU on lending. Bordo et al. (2016), Chi and Li (2017), and Hu and Gong (2019) show that EPU leads to a decrease in credit growth and non-performing loan ratios by using bank-level data and Caglayan and $\mathrm{Xu}$ (2019) and Gozgor et al. (2019) document similar findings on the macro-level. Furthermore, Broll et al. (2018) and Moudud-Ul-Huq (2019) use this indicator to analyze the risk preferences of the banks.

However, to our knowledge, this is the first paper that explores whether the impact of economic uncertainty (WUI) on credit growth differs for Islamic and conventional banks. By using an international sample of 416 banks (58 Islamic and 358 conventional) in 12 countries, we find that an increase in economic uncertainty has a negative impact on the credit growth of conventional banks while no effect is documented for Islamic banks' credit growth. Our results are robust to using alternative variables and addressing endogeneity with GMM estimators. This finding supports the view that Islamic banks' lending behavior is immune to changes to fluctuations in economic conditions.

The rest of the paper is organized as follows. Section 2 provides details on the data and methodology. Section 3 presents and discusses the findings. Section 4 concludes the paper.

\section{Data and Methodology}

Our bank-level data is from Fitch Connect and macroeconomic data is obtained from World Bank World Development Indicators. Financial development and bank regulation data are extracted from the World Bank Global Financial Development Database and World Bank Regulation and Supervision Surveys. Following Islam and Rizvi (2018), our initial sample includes only the dual-banking countries that are characterized by a significant presence of Islamic banks. We further follow the filtration implemented by Beck et al. (2013) and include countries with at least four banks with at least three years of consecutive data, which leaves a final sample of 416 banks (58 Islamic and 358 conventional) in 12 countries for the period from 2009 to 2018. The list of countries and the respective number of banks are displayed in Table A1 in the Appendix. 
To explore the influence of economic uncertainty on the credit growth of Islamic and conventional banks, we estimate the following baseline model following Abedifar et al. (2013) and Bitar and Tarazi (2019):

Credit growth gijt $=\gamma W U I_{j t}+\delta I S L A M I C_{i j t}+\partial W U I_{j t} * I S L A M I C_{i j t}+$

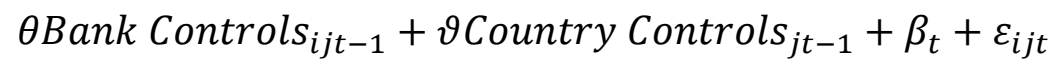

where $\mathrm{i}, \mathrm{j}$ and $\mathrm{t}$ stand for bank, country and time, respectively. We include year dummies throughout all specifications. The estimations are conducted using the random-effects GLS method following the extant literature on Islamic banking (Islam and Rizvi, 2018; Abedifar et al., 2013; Bitar and Tarazi, 2019). Random-effects GLS is chosen due to two important reasons: First, methods such as ordinary least squares (OLS) do not take into account the panel structure of the data. Second, the Islamic bank dummy in our model is time-invariant and therefore a fixed effect model would be irrelevant. For robustness, we use dynamic panel data estimation techniques using a two-step system GMM method with robust standard errors, which is estimated by the following regression:

Credit growth $h_{i j t}=$ Credit growth $_{i j t-1}+\gamma W U I_{j t}+\delta I S L A M I C_{i j t}+$

$\partial$ WUI $_{j t} *$ ISLAMIC $_{i j t}+\theta$ Bank Controls $_{i j t-1}+\vartheta$ Country Controls $_{j t-1}+\beta_{t}+\varepsilon_{i j t}$

Our dependent variable is CREDIT GROWTH, which is the annual growth rate of bank loans. WUI is the world economic uncertainty index constructed by Ahir et al. (2018) and counts the frequencies of the word "uncertainty" (and its variants) in the Economist Intelligence Unit (EIU) country reports. The values are comparable across countries because the index is based on a single source and the raw counts are scaled by the total number of words in each report (Ahir et al., 2018). Therefore, it is superior compared to other uncertainty measures (Gozgor et al. 2019). ISLAMIC is a dummy variable that equals 1 for Islamic banks and 0 for conventional banks. Bank Controls are chosen from the bank-specific determinants of bank lending prevalent in the literature, mainly following Hu and Gong (2019) and Nguyen et al. (2020). They include DEPOSIT SHARE calculated as total deposits/total assets; LISTED which is a dummy variable for listed banks; 0 otherwise; SIZE measured as the natural logarithm of total assets; EQUITY SHARE calculated as the share of equity to total assets; LLP which denotes the ratio of loan loss provisions to net interest revenue and COST TO INCOME measured as total costs/total income. Country Controls incorporate the 
macroeconomic and financial development variables which are listed in Table 1 together with descriptive statistics:

\section{>>>>INSERT TABLE 1 HERE $<<<<$}

The correlation coefficients between the independent variables are provided in Appendix Table A2 which do not indicate major multicollinearity issues.

\section{Findings}

The findings are displayed in Table 2 where Column 1 includes only bank controls and Columns 2 and 3 incorporate additional macro and financial development controls. The negative and significant coefficient of WUI in Columns 1-3 reveal that an increase in economic uncertainty has a negative impact on the credit growth of conventional banks. The negative impact is not only statistically but also economically sizeable, as one standard deviation increase in uncertainty (0.13) depresses the growth rate of credits by 4.57 percentage points $\left(35.162 \%{ }^{*} 0.13\right)$. This is consistent with the view that conventional banks have a tendency of restraining credits when the level of uncertainty elevates (Bordo et al., 2016; Chi and Li, 2017; Hu and Gong, 2019). However, for Islamic banks, as displayed in Table 2 the sum of coefficients of ISLAMIC and ISLAMIC*WUI variables is insignificant showing that we observe no significant effect of WUI on Islamic banks' credit growth. Therefore, under uncertainties, while conventional banks tend to significantly decrease their lending, Islamic banks do not adjust their behavior and lending is unaffected from the uncertainty fluctuations. For robustness, Column 4 and 5 split the sample into Islamic and conventional banks and confirm our main findings. Column 6 employs a two-step system GMM and our results are robust under a dynamic model with the diagnostic tests (the Hansen test and $\mathrm{AR}(1)$ and $\mathrm{AR}(2)$ tests) supporting the validity of the two-step system GMM dynamic model.

\section{>>> INSERT TABLE 2 HERE $<<<<$}

Table 3 provides some additional insights by splitting the sample along important country characteristics, mainly following Mollah et al. (2017) and Abedifar et al. (2013). It shows the results for the estimations of countries that have explicit deposit insurance for Islamic banks vs. those who do not (Columns 1 and 2), and high vs. low foreign presence (Columns 3 and 
4), where foreign bank assets/total assets is higher vs. lower than the 75th percentile, respectively. To gain insight into whether the results would differ for the countries that have different Islamic bank presence, we conduct the estimations in Columns 5\&6 for countries that have a high vs. low share deposits share in Islamic banks where the percentage of the banking system's deposits in Islamic banks is higher vs. lower than 50th percentile, respectively. Moreover, in Columns $7 \& 8$ we include an additional proxy for Islamic bank presence and use the percentage of the banking system's assets in Islamic banks and whether the share is higher vs. lower than $50^{\text {th }}$ percentile, respectively.

We observe that our findings are stronger under the following specifications: (1) countries with explicit deposit insurance protection system for Islamic banks, (2) lower foreign dominance, and (3) countries with a higher share of deposits and assets in Islamic banks. Therefore, these observations imply that the lending behavior of Islamic banks are immune to and lending growth of conventional banks is negatively affected by economic uncertainties for countries that provide special protection for Islamic banks through an explicit deposit insurance mechanism; and for the countries that have lower foreign assets, but higher Islamic bank presence.

The control variables have generally expected signs. Specifically, bank credit growth increases for banks with higher equity share and cost-to-income and for countries with higher GDP growth and unemployment. On the other hand, bank lending decreases for banks with higher deposits and loan loss provisions share and larger banks.

\section{>>>>INSERT TABLE 3 HERE $<<<<$}

\section{Conclusion}

We examine whether the effect of economic uncertainty on credit growth differs for Islamic vs. conventional banks. Using a sample of 416 banks (58 Islamic and 358 conventional) in 12 countries, the paper documents that a rise in economic uncertainty has a negative effect on the credit growth of conventional banks but does not have any significant impact on Islamic banks' credit growth. Our results are robust to the use of alternative variables and specifications. Moreover, a deeper investigation reveals that Islamic banks are more strongly immune to economic uncertainty downturns in countries with explicit deposit insurance protection for Islamic banks, lower foreign presence, and countries with a higher share of 
deposits and assets in Islamic banks. Our findings contribute to our knowledge on financial intermediation and have several policy implications. Conventional banks operate alongside with Islamic banks in more and more countries around the world. Where this is the case, regulators and policy makers need to closely consider the structure of the banking system when designing policies to ensure that banks continue to lend to contribute to the real economy in times of higher uncertainty.

\section{References}

Abedifar, P., Molyneux, P., \& Tarazi, A. (2013). Risk in Islamic banking. Review of Finance, 17(6), 2035-2096.

Ahir, H., Bloom, N., \& Furceri, D. (2018). The world uncertainty index. Available at SSRN 3275033.

Baker, S.R., Bloom, N., \& Davis, S.J. (2016). Measuring economic policy uncertainty. The quarterly journal of economics, 131(4), 1593-1636.

Beck, T., Demirgüç-Kunt, A., \& Merrouche, O. (2013). Islamic vs. conventional banking: Business model, efficiency and stability. Journal of Banking \& Finance, 37, 433-447.

Bitar, M., \& Tarazi, A. (2019). Creditor rights and bank capital decisions: Conventional vs. Islamic banking. Journal of Corporate Finance, 55, 69-104.

Bordo, M.D., Duca, J.V., \& Koch, C. (2016). Economic Policy Uncertainty and the Credit Channel: Aggregate and Bank Level U.S. Evidence over Several Decades. Journal of Financial Stability, 26, 90-106.

Broll, U., Welzel, P. \& Wong, K.P. (2018). Ambiguity preferences, risk taking and the banking firm. Eurasian Economic Review, 8(3), 343-353.

Caglayan, M. and Xu, B., 2019. Economic policy uncertainty effects on credit and stability of financial institutions. Bulletin of Economic Research, 71(3), 342-347

Chi, Q., \& Li, W. (2017). Economic policy uncertainty, credit risks and banks' lending decisions: Evidence from Chinese commercial banks. China journal of accounting research, 10(1), 33-50.

Gozgor, G., Demir, E., Belas, J. and Yesilyurt, S. 2019. Does Economic Uncertainty Affect Domestic Credits? An Empirical Investigation. Journal of International Financial Markets, Institutions and Money, forthcoming.

Hasan, M., \& Dridi, J. (2011). The effects of the global crisis on Islamic and conventional banks: A comparative study. Journal of International Commerce, Economics and Policy, 2(02), 163-200. 
Hu, S., \& Gong, D. (2019). Economic policy uncertainty, prudential regulation and bank lending. Finance Research Letters, 29, 373-378.

Ibrahim, M. H., \& Rizvi, S.A.R. (2018). Bank lending, deposits and risk-taking in times of crisis: A panel analysis of Islamic and conventional banks. Emerging Markets Review, 35, 31-47.

Ibrahim, M. H. (2016). Business cycle and bank lending procyclicality in a dual banking system. Economic Modelling, 55, 127-134.

Khediri, K. B., Charfeddine, L., \& Youssef, S. B. (2015). Islamic versus conventional banks in the GCC countries: A comparative study using classification techniques. Research in International Business and Finance, 33, 75-98.

Mollah, S., Hassan, M. K., Al Farooque, O., \& Mobarek, A. (2017). The governance, risk-taking, and performance of Islamic banks. Journal of financial services research, 51(2), 195-219.

Moudud-Ul-Huq, S. (2019). Banks' capital buffers, risk, and efficiency in emerging economies: are they counter-cyclical? Eurasian Economic Review, 9(4), 467-492.

Nguyen, C. P., Le, T. H., \& Su, T. D. (2020). Economic policy uncertainty and credit growth: Evidence from a global sample. Research in International Business and Finance, 51, 101118. 
Table 1. Variables and descriptive statistics

\begin{tabular}{|c|c|c|c|}
\hline Variables & & Mean & SD \\
\hline Dependent variables & Description & & \\
\hline CREDIT GROWTH & Annual growth of gross loans & $22.99 \%$ & $34.20 \%$ \\
\hline \multicolumn{4}{|l|}{ Independent variables } \\
\hline WUI & & 0.14 & 0.13 \\
\hline ISLAMIC & for Islamic banks; 0 for conventional banks & 0.14 & 0.35 \\
\hline DEPOSIT SHARE & $\begin{array}{l}\text { Total deposits/total assets } \\
\text { A dummy variable equals } 1 \text { for publicly listed }\end{array}$ & $66.28 \%$ & $19.78 \%$ \\
\hline LISTED & banks; 0 otherwise & 0.46 & 0.50 \\
\hline SIZE & Ln (total assets) & 7.82 & 1.86 \\
\hline EQUITY SHARE & Equity to total assets & $16.66 \%$ & $15.53 \%$ \\
\hline LLP & Loan loss provisions/ net interest revenue & $20.29 \%$ & $29.70 \%$ \\
\hline COST TO INCOME & Total costs/ total income & $56.11 \%$ & $28.58 \%$ \\
\hline \multicolumn{4}{|l|}{ Country Controls } \\
\hline GDP GROWTH & Real GDP growth rate & $5.12 \%$ & $2.21 \%$ \\
\hline UNEMPLOYMENT & Unemployment rate (\% of total labor force) & $5.59 \%$ & $3.49 \%$ \\
\hline OIL MINERAL & Oil and mineral rents as a share of GDP & $7.27 \%$ & $12.13 \%$ \\
\hline CREDIT TO PRIVATE & Domestic credit to private sector ( $\%$ of GDP) & $51.98 \%$ & $28.59 \%$ \\
\hline INTEREST RATE & $\begin{array}{l}\text { Lending interest rate } \\
\text { Takes a value of } 1 \text { if the country has an }\end{array}$ & $10.51 \%$ & $3.63 \%$ \\
\hline DEPOSIT INSURANCE & $\begin{array}{l}\text { explicit deposit insurance protection system } \\
\text { for Islamic banks; } 0 \text { otherwise }\end{array}$ & 0.70 & 0.46 \\
\hline FOREIGN DOMINANCE & $\begin{array}{l}\text { Foreign bank assets among total bank } \\
\text { assets (\%) }\end{array}$ & $18.23 \%$ & $13.90 \%$ \\
\hline $\begin{array}{l}\text { DEPOSITS IN ISLAMIC } \\
\text { BANKS }\end{array}$ & $\begin{array}{l}\text { The percentage of the banking system's } \\
\text { deposits in Islamic banks }\end{array}$ & $12.82 \%$ & $10.15 \%$ \\
\hline ASSETS IN ISLAMIC BANKS & $\begin{array}{l}\text { The percentage of the banking system's } \\
\text { assets in Islamic banks }\end{array}$ & $11.75 \%$ & $9.62 \%$ \\
\hline
\end{tabular}


Table 3: The effect of WUI on credit growth of Islamic vs. Conventional banks: Split samples into country characteristics

\begin{tabular}{|c|c|c|c|c|c|c|c|c|}
\hline & $\begin{array}{l}\text { (1) (Deposit } \\
\text { insurance) }\end{array}$ & $\begin{array}{c}\text { (2) (No } \\
\text { Deposit } \\
\text { insurance) }\end{array}$ & $\begin{array}{c}\text { (3) (High } \\
\text { Foreign } \\
\text { dominance) }\end{array}$ & $\begin{array}{c}\text { (4) (Low } \\
\text { Foreign } \\
\text { dominance) }\end{array}$ & $\begin{array}{c}\text { (5) High } \\
\text { share of } \\
\text { deposits } \\
\text { in Islamic } \\
\text { banks }\end{array}$ & $\begin{array}{c}\text { (6) Low } \\
\text { share of } \\
\text { deposits } \\
\text { in } \\
\text { Islamic } \\
\text { banks }\end{array}$ & $\begin{array}{l}\text { (7) High } \\
\text { share of } \\
\text { assets in } \\
\text { Islamic } \\
\text { banks }\end{array}$ & $\begin{array}{c}\text { (8) Low } \\
\text { share of } \\
\text { assets } \\
\text { in } \\
\text { Islamic } \\
\text { banks } \\
\end{array}$ \\
\hline \multirow{2}{*}{$\overline{\text { ISLAMIC }}$} & $-8.657^{*}$ & 3.95 & 0.185 & $-10.109^{*}$ & -7.622 & $-16.170^{*}$ & -7.694 & $-15.883^{*}$ \\
\hline & -4.772 & -6.915 & -4.061 & -5.291 & -4.779 & -8.266 & -4.769 & -8.349 \\
\hline \multirow[t]{2}{*}{ WUI } & $-22.935^{*}$ & $28.344^{\star * *}$ & -9.108 & $-15.826^{* *}$ & $-29.212^{\star \star *}$ & $25.201^{*}$ & $-28.465^{\star \star *}$ & $24.854^{*}$ \\
\hline & -13.101 & -9.705 & -13.1 & -7.601 & -8.762 & -14.292 & -8.709 & -14.469 \\
\hline \multirow[t]{2}{*}{ ISLAMIC*WUI } & $50.558^{\star *}$ & -21.711 & 7.713 & 41.09 & $34.976^{*}$ & $92.685^{\star *}$ & $34.401^{*}$ & $92.602^{\star \star}$ \\
\hline & -25.778 & -61.107 & -34.927 & -26.275 & -20.861 & -42.986 & -20.84 & -43.129 \\
\hline \multirow[t]{2}{*}{ L.LISTED } & $-6.638^{* *}$ & $-8.463^{* *}$ & -1.879 & $-7.076^{* *}$ & -5.273 & $-6.170^{*}$ & -5.309 & $-6.233^{*}$ \\
\hline & -2.853 & -3.571 & -1.611 & -2.92 & -3.414 & -3.209 & -3.403 & -3.222 \\
\hline \multirow[t]{2}{*}{ L.SIZE } & -0.981 & -1.007 & $-1.221^{* *}$ & $-3.452^{\star * *}$ & -1.78 & -0.884 & -1.758 & -0.885 \\
\hline & -0 . & -1 & & -0 & -1 & -1.025 & -1.129 & -1.027 \\
\hline \multirow[t]{2}{*}{ L.EQUITY SHARE } & 0.95 & 0.0 & 0.50 & 0.32 & $0.736^{\star \star \star}$ & $0.516^{\star * *}$ & $0.733^{* * *}$ & $0.517^{* * *}$ \\
\hline & -0 & -0. & & & -0 & -0.102 & & -0.103 \\
\hline \multirow[t]{2}{*}{ L.LOAN SHARE } & -0.003 & $-0.185^{\star \star *}$ & -0.6 & -0.1 & $-0.062^{* *}$ & 0.032 & $-0.061^{* *}$ & 0.031 \\
\hline & -0.026 & -0.071 & -0.0 & -0 . & -0.03 & -0.033 & -0.03 & -0.033 \\
\hline \multirow[t]{2}{*}{ L.COST TO INCOME } & $0.213^{* * *}$ & $0.380^{* * *}$ & $0.149^{* * *}$ & $0.249^{* * *}$ & $0.166^{\star * *}$ & $0.284^{* * *}$ & $0.164^{* * *}$ & $0.284^{* * *}$ \\
\hline & -0.041 & -0.066 & -0.035 & -0.048 & -0.044 & -0.049 & -0.044 & -0.05 \\
\hline \multirow[t]{2}{*}{ L.GDP GROWTH } & 0.352 & 0.496 & $1.852^{* *}$ & $0.797^{*}$ & $1.072^{\star \star \star}$ & -0.772 & $1.109^{* * *}$ & -0.895 \\
\hline & -0.69 & -0.554 & -0.744 & -0.411 & -0.366 & -1.05 & -0.363 & -1.143 \\
\hline \multirow[t]{2}{*}{ L.UNEMPLOYMENT } & $3.570^{* * *}$ & 0.456 & 0.11 & 0.477 & $0.697^{*}$ & $1.694^{*}$ & $0.721^{*}$ & $1.659^{*}$ \\
\hline & -1.279 & -0.426 & -0.255 & -0.398 & -0.374 & -0.978 & -0.372 & -0.983 \\
\hline \multirow[t]{2}{*}{ L.OIL MINERAL } & $-0.206^{*}$ & $0.671^{* *}$ & 0.157 & -0.067 & -0.14 & $3.192^{* *}$ & -0.134 & $3.026^{* *}$ \\
\hline & -0.121 & -0.273 & -0.308 & -0.117 & -0.119 & -1.306 & -0.119 & -1.431 \\
\hline \multirow[t]{2}{*}{ CONSTANT } & -0.237 & 10.858 & $17.104^{* *}$ & $38.710^{* * *}$ & 14.887 & -1.131 & 14.333 & 0.269 \\
\hline & -11.773 & -12.854 & -8.583 & -10.374 & -11.347 & -14.233 & -11.281 & -15.036 \\
\hline$\overline{\mathrm{R} 2}$ & 0.1182 & 0.2351 & 0.1299 & 0.1838 & 0.096 & 0.2058 & 0.0968 & 0.1931 \\
\hline Observations & 1589 & 601 & 1175 & 1272 & 1347 & 1100 & 1352 & 1095 \\
\hline Number of Banks & 237 & 94 & 359 & 302 & 261 & 158 & 261 & 157 \\
\hline Year FE & YES & YES & YES & YES & & & & \\
\hline
\end{tabular}

Notes: This table shows the WUI and credit growth relationship by splitting the sample into some country characteristics. The estimations are conducted using random effects, generalized least square (GLS) regressions. CREDIT GROWTH is used as dependent variable in all columns. Column 1 (Column 2) show countries which have (do not have) explicit deposit insurance for Islamic banks. Column 3 (Column 4) indicate high (low) foreign dominance countries when foreign bank assets/total assets is higher than 75th percentile (lower than 75th percentile). Column 5\&7 (Column 6\&8) display high (low) share of deposits (assets) in Islamic banks when the percentage of the banking system's deposits (assets) in Islamic banks is higher than 50th percentile (lower than 50th percentile). Robust Standard errors reported in parentheses. ${ }^{*} p<0.10,{ }^{* *} p<0.05,{ }^{* * *} p<0.01$ 


\section{Appendix}

Table A1. List of Countries and Number of Bank for Each Type

\begin{tabular}{lccc}
\hline & Islamic Banks & Conventional Banks & Total \\
\hline BANGLADESH & 5 & 49 & 54 \\
EGYPT & 1 & 24 & 25 \\
INDONESIA & 8 & 113 & 121 \\
JORDAN & 3 & 11 & 14 \\
KUWAIT & 3 & 14 & 17 \\
MALAYSIA & 15 & 29 & 44 \\
PAKISTAN & 5 & 29 & 34 \\
QATAR & 5 & 8 & 13 \\
SAUDI ARABIA & 3 & 10 & 13 \\
TURKEY & 1 & 45 & 46 \\
UNITED ARAB EMIRATES & 6 & 22 & 28 \\
YEMEN & 3 & 4 & 7 \\
\hline Total & $\mathbf{5 8}$ & $\mathbf{3 5 8}$ & $\mathbf{4 1 6}$ \\
\hline
\end{tabular}


Table A2. Correlations

\begin{tabular}{|c|c|c|c|c|c|c|c|c|c|c|c|c|c|}
\hline & $(1)$ & $(2)$ & (3) & $(4)$ & $(5)$ & (6) & $(7)$ & $(8)$ & (9) & $(10)$ & $(11)$ & $(12)$ & $(13)$ \\
\hline (1) WUI & 1 & & & & & & & & & & & & \\
\hline (2) ISLAMIC & $-0.0931^{*}$ & 1 & & & & & & & & & & & \\
\hline (3) DEPOSIT SHARE & $-0.1916^{*}$ & $0.0527^{*}$ & 1 & & & & & & & & & & \\
\hline (4) LISTED & $-0.0754^{*}$ & $-0.0585^{*}$ & $0.2919^{*}$ & 1 & & & & & & & & & \\
\hline (5) SIZE & $0.0358^{*}$ & $0.0655^{*}$ & $0.2154^{*}$ & $0.3394^{*}$ & 1 & & & & & & & & \\
\hline (6) EQUITY SHARE & $0.0940^{*}$ & $-0.0372^{*}$ & $-0.5988^{*}$ & $-0.1599^{*}$ & $-0.4892^{*}$ & 1 & & & & & & & \\
\hline (7) LLP & -0.0093 & $0.0370^{*}$ & 0.0048 & $0.0748^{*}$ & 0.0179 & -0.0112 & 1 & & & & & & \\
\hline (8) COST TO INCOME & 0.0116 & $0.0362^{*}$ & $0.0362^{*}$ & $-0.0600^{*}$ & $-0.3886^{*}$ & $0.1366^{*}$ & $0.2199^{*}$ & 1 & & & & & \\
\hline (9) GDP GROWTH & -0.0272 & -0.0251 & $-0.0535^{\star}$ & $-0.1038^{*}$ & $-0.1195^{*}$ & 0.019 & $-0.0435^{*}$ & $0.0557^{*}$ & 1 & & & & \\
\hline (10) UNEMPLOYMENT & $0.3928^{*}$ & $-0.1282^{*}$ & 0.014 & -0.0324 & 0.0168 & -0.0215 & $-0.0401^{*}$ & $-0.0445^{*}$ & $-0.0975^{\star}$ & 1 & & & \\
\hline (11) OIL MINERAL & $-0.0402^{*}$ & $0.1166^{*}$ & 0.02 & $0.2425^{*}$ & $0.2530^{*}$ & $0.1235^{\star}$ & $0.1236^{*}$ & $-0.0807^{*}$ & $-0.0851^{*}$ & $-0.1806^{*}$ & 1 & & \\
\hline (12) CREDIT TO PRIVATE & $0.0473^{*}$ & $0.2137^{*}$ & $-0.2217^{*}$ & $-0.1149^{*}$ & $0.2017^{\star}$ & $0.0620^{*}$ & $0.0451^{*}$ & $-0.0839^{*}$ & $-0.0901^{*}$ & $-0.1071^{*}$ & $0.1647^{\star}$ & 1 & \\
\hline (13) INTEREST RATE & $0.0636^{\star}$ & $-0.2081^{*}$ & $0.2574^{*}$ & 0.0009 & $-0.2833^{\star}$ & $-0.1398^{*}$ & 0.0037 & $0.0393^{*}$ & $0.0805^{\star}$ & $0.3097^{*}$ & $-0.4002^{*}$ & $-0.8270^{*}$ & 1 \\
\hline
\end{tabular}

